\title{
Evidence of prokaryotic metabolism on suspended particulate organic matter in the dark waters of the subtropical North Atlantic
}

\section{Federico Baltar ${ }^{1}$ and Javier Arístegui}

Facultad de Ciencias del Mar, Universidad de Las Palmas de Gran Canaria, Campus Universitario de Tafira, 35017 Las Palmas de Gran Canaria, Spain

Josep M. Gasol

Departament de Biologia Marina i Oceanografia, Institut de Ciències del Mar - CSIC, Pg. Marítim de la Barceloneta 37-49, 08003 Barcelona, Spain

\section{Eva Sintes and Gerhard J. Herndl}

Department of Biological Oceanography, Royal Netherlands Institute for Sea Research (NIOZ), P.O. Box 59, 1790 AB Den Burg, The Netherlands

\begin{abstract}
The distribution of prokaryotic abundance (PA), respiratory activity (ETS), heterotrophic production (PHP), and suspended particulate (POM) and dissolved (DOM) organic matter was determined in the meso- and bathypelagic waters of the (sub)tropical North Atlantic. PA decreased by one order of magnitude from the lower euphotic zone to the bathypelagic waters, while ETS decreased by two and PHP by three orders of magnitude. On a section following the Mid-Atlantic Ridge from $35^{\circ} \mathrm{N}$ to $5^{\circ} \mathrm{N}$, ETS below $1000-\mathrm{m}$ depth increased southwards up to three-fold. This latitudinal gradient in the deep waters was paralleled by a six-fold increase in Particulate Organic Carbon (POC), whereas no trend was apparent in the DOM distribution. Significant correlations between POM and ETS were obtained in the water masses between 1000-m and 3000-m depth, the Antarctic Intermediate Water and the North East Atlantic Deep Water. A strong imbalance in the dark ocean was found between prokaryotic carbon demand (estimated through two different approaches) and the carbon sinking flux derived from sediment-trap records corrected with ${ }^{230} \mathrm{Th}$. The imbalance was greater when deeper in the water column, suggesting that the suspended carbon pool must account for most of the carbon deficit. Our results, together with other recent findings discussed in this paper, indicate that microbial life in the dark ocean is likely more dependent on slowly sinking or buoyant, laterally advected suspended particles than hitherto assumed.
\end{abstract}

For a long time, the dark ocean was considered to be a site of almost negligible biological activity due to the harsh environmental conditions (Morita 1984). Over the last two decades, however, the relatively intense microbial activity

\footnotetext{
${ }^{1}$ Corresponding author (federico.baltar102@doctorandos. ulpgc.es).

\section{Acknowledgments}

We thank the captain and crew of R/V Pelagia for their help during work at sea. S. Gonzalez and K. Bakker performed the Total Organic Carbon and nutrient analyses, respectively, and A. Smit the leucine incorporation measurements. M. F. Montero and M. Espino helped with the Electron Transport System analyses and I. J. Alonso-González with the particulate organic-matter measurements. Water masses were identified by H. M. van Aken. We also thank two anonymous reviewers for their comments and suggestions to improve the manuscript. This research was supported by a predoctoral Fellowship of the Spanish Ministry of Education and Science (AP2005-3932) to F.B., a grant of the Earth and Life Science Division of the Dutch Science Foundation (ALW-NWO; ARCHIMEDES project, 835.20.023) to G. J. H. and a grant of the Spanish Ministry of Education and Science to J. A. (Remolinos Oceánicos y Deposiciones Atmosféricas (RODA) project; CTM 2004-06842-C03/MAR). The work was carried out within the frame of the EU 'Networks of Excellence' MarBef and EurOceans. This work is in partial fulfillment of the requirements for a Ph.D. degree from the University of Las Palmas by F.B.
}

taking place in the dark ocean has been recognized (Cho and Azam 1988; Karl et al. 1988; Simon et al. 1992). In particular, deep-ocean respiration has been estimated to account for one-third of the biological $\mathrm{CO}_{2}$ production in the ocean (del Giorgio and Duarte 2002; Arístegui et al. 2005a). These high respiration rates, however, largely exceed the downward export flux of dissolved (DOC) and sinking particulate organic carbon (POC; Reinthaler et al. 2006). Arístegui et al. (2002) showed that, based on the relation between DOC and apparent oxygen utilization (AOU) in a large global-ocean data set, DOC accounts for only $10-20 \%$ of oxygen consumption in the dark ocean, supporting the view that the bulk of dark ocean respiration is driven by particulate material (McCave 1975; Honjo 1980; Arístegui et al. 2005a). Their results agree with the study of Hansell and Carlson (1998), who inferred extremely low remineralization rates from basin-scale gradients of DOC in the deep ocean. However, the sinking POC supply collected with sediment traps, commonly used for inferring remineralization rates in the ocean, does not explain the remaining oxygen consumption in the dark waters (Arístegui et al. 2005a; Reinthaler et al. 2006). One explanation of this discrepancy could be that the suspended (or low-buoyancy) fraction of the suspended particulate organic matter (POM) pool is underestimated (or simply not collected) with sediment traps. This pool is quantita- 
tively far larger than the sinking pool (McCave 1984; Verdugo et al. 2004), and might account for the excess oxygen consumption rates. This suspended POM might be laterally transported through intermediate and deep waters while being remineralized. Bauer and Druffel (1998) concluded, from a study comparing the natural radiocarbon abundance in two coastal and open-ocean profiles in the North Atlantic and North Pacific Oceans, that the POC inputs from ocean margins to the ocean interior could be more than one order of magnitude higher than the input of recently produced organic carbon derived from the surface ocean. Regardless, whether the suspended carbon in the dark ocean is transported from ocean margins or originates from sinking particles, this pool has been largely ignored in ocean carbon budgets.

In this study we investigated regional gradients and the depth distribution of the dissolved (DOM) and particulate organic matter (POM) pools, as well as the microbial metabolism in the dark ocean to determine the relation between changes in the OM pools and the activity of deepwater microbes in the (sub)tropical North Atlantic. To address this question, we determined the potential respiration via electron transport system (ETS) measurements along with particulate and dissolved organic carbon (POC and DOC) and nitrogen (PON and DON), as well as prokaryotic abundance and production in the mixed layer ( $\approx 50$-m depth), the upper thermocline $(\approx 100$-m depth), the mesopelagic (200-1000-m depth), and bathypelagic (10004500-m depth) waters of the (sub)tropical North Atlantic. DOC is largely refractory below the mixed layer of the (sub)tropical regions (Hansell and Carlson 2002) where overturning circulation is greatly restricted, and the sinking fluxes are low in open-ocean waters. Thus, we hypothesized that the metabolism of prokaryotes in the dark ocean largely relies on suspended particles, which we would be able to measure as POM. Hence, variations in the distribution of POM collected with oceanographic bottles, considered to be mostly suspended detrital material, should be related to variations in prokaryotic metabolism in the dark ocean.

\section{Methods}

Study site and sampling-To resolve the areal variability in organic matter and prokaryotic activity in the meso- and bathypelagic waters of the eastern North Atlantic, $>9000 \mathrm{~km}$ were covered comprising the subtropical gyre region (SG) and the North Equatorial Counter Current region (NEqCC; Fig. 1) on board RV Pelagia (Nov-Dec 2005). The study area was divided into two regions (SG and NEqCC; Varela et al. 2008) separated by the latitudinal front of the intermediate and central waters (see Fig. 1). The circulation pattern of the bathypelagic water masses, however, did not differ across the two regions. Samples were taken at 25 out of 43 stations occupied during the ARCHIMEDES-I cruise from seven depths: the surface mixed layer (SML, average depth $50 \mathrm{~m}$ ) for POM and ETS only, the base of the mixed layer ("subsurface", 100-m layer), the oxygen minimum layer (OML; average depth $400 \mathrm{~m}$ ), the Mediterranean Sea Overflow Water (MSOW;

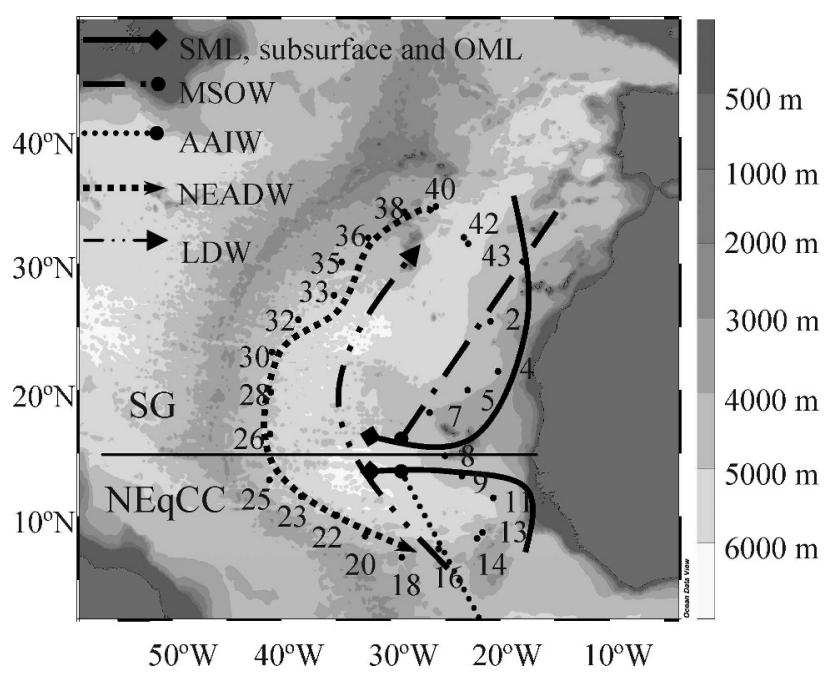

Fig. 1. Stations occupied during ARCHIMEDES-I. Sampled stations are indicated by numbered dots. Horizontal line at $\sim 15^{\circ} \mathrm{N}$ separates the stations of the subtropical gyre (SG) from those in the North Equatorial Counter Current (NEqCC). The section plotted in Fig. 4 extends from Sta. 40 to Sta. 16. Lines indicate the flow pattern of the main water masses. For water mass abbreviation see Table 1 .

average depth $900 \mathrm{~m}$ ) in the SG, the Antarctic Intermediate Water (AAIW; average depth $900 \mathrm{~m}$ ) in the NEqCC, the North East Atlantic Deep Water (NEADW; average depth $2750 \mathrm{~m}$ ), and the Lower Deep Water (LDW; average depth $4000 \mathrm{~m}$ ). The specific water masses were identified based on their distinct temperature-salinity characteristics, oxygen content, and inorganic nutrient signatures (Table 1). The LDW, characterized by low salinity (34.9) and temperature $\left(2.3-2.6^{\circ} \mathrm{C}\right)$, consisted mainly of Antarctic Bottom Water coming from the south and mixed with some NEADW. Iceland Scotland Overflow Water and Labrador Sea Water principally form the NEADW (Varela et al. 2008). Samples from the distinct water masses were collected with 12-liter NOEX (no oxygen exchange) bottles mounted on a CTD (conductivity, temperature, depth) frame to determine total picoplankton abundance, leucine incorporation, POM, DOM, and ETS as described below.

Prokaryotic abundance (PA) determined by flow cytometry-Picoplankton collected from the different depth layers of the water column were enumerated using flow cytometry. Samples $(2 \mathrm{~mL})$ were fixed with $1 \%$ paraformaldehyde (final concentration), shock-frozen in liquid nitrogen for $5 \mathrm{~min}$ and stored at $-80^{\circ} \mathrm{C}$. Picoplankton cells were stained with SYBR-Green I and enumerated within 3 months with a FACSCalibur flow cytometer (Becton Dickinson) equipped with a 488-nm laser. Immediately before analysis, the thawed picoplankton samples were diluted 5- to 10-fold in TE buffer $\left(10 \mathrm{mmol} \mathrm{L}^{-1}\right.$ Tris, $1 \mathrm{mmol} \mathrm{L}-1$ EDTA, potential Hydrogen $[\mathrm{pH}]$ 8) and stained with SYBR-Green I at room temperature in the dark for $15 \mathrm{~min}$. Fluorescent microspheres (Molecular Probes) with a diameter of $1 \mu \mathrm{m}$ were added to all samples as an internal standard. Picoplankton cells were differentiated according to their right-angle scatter and green 
Table 1. Characteristics of the main water masses sampled during the ARCHIMEDES-I cruise based on conductivity, temperature, depth (CTD) profiles at individual stations. Ranges are given for each water mass where samples were collected. SG: Subtropical Gyre, NEqCC: North Equatorial Counter Current, SML: surface mixed layer, OML: oxygen minimum layer, MSOW: Mediterranean Sea Overflow Water, NEADW: North East Atlantic Deep Water, LDW: Lower Deep Water, AAIW: Antarctic Intermediate Water.

\begin{tabular}{|c|c|c|c|c|c|}
\hline Zone & Water mass & Depth (m) & Temperature $\left({ }^{\circ} \mathrm{C}\right)$ & Salinity & Oxygen $\left(\mu \mathrm{mol} \mathrm{kg} \mathrm{kg}^{-1}\right)$ \\
\hline \multicolumn{6}{|l|}{ SG } \\
\hline & SML & 50 & $20.1-26.8$ & $36.5-37.2$ & $178.5-213.1$ \\
\hline & subsurface & 100 & $17.7-24.1$ & $36.4-37.5$ & $138.9-221.5$ \\
\hline & OML & $250-500$ & $10.1-17.9$ & $35.3-36.5$ & $87.5-207.2$ \\
\hline & MSOW & $900-1000$ & $7.6-9.2$ & $35.1-35.6$ & $121.2-197.7$ \\
\hline & NEADW & 2750 & $2.8-3.0$ & 34.9 & $223.8-250.8$ \\
\hline & LDW & $3500-5000$ & $2.4-2.6$ & 34.9 & $223.7-242.5$ \\
\hline NEqCC & SML & 50 & $19.4-27.8$ & $35.9-36.1$ & $118-184.5$ \\
\hline & subsurface & 100 & $14.2-18.5$ & $35.5-36.4$ & $79.6-132.7$ \\
\hline & OML & $250-500$ & $7.9-12.0$ & $34.7-35.3$ & $44.0-122.3$ \\
\hline & AAIW & $900-1000$ & $5.1-6.5$ & $34.6-34.7$ & $102.4-129.5$ \\
\hline & NEADW & 2750 & $2.8-3.0$ & 34.9 & $234.3-247.1$ \\
\hline & LDW & $3750-4000$ & $2.3-2.4$ & 34.9 & $227.7-246.8$ \\
\hline
\end{tabular}

fluorescence. The counting window of the flow cytometer was set to exclude the occasionally present eukaryotic picoplankton. Prokaryotic carbon biomass was calculated assuming a carbon content of $10 \mathrm{fg} \mathrm{C}$ per cell, which seems to be most suitable for dark ocean prokaryotes (Ducklow 2000).

Prokaryotic heterotrophic production (PHP) estimated by $\left[{ }^{3} \mathrm{H}\right]$ leucine incorporation-Bulk picoplankton heterotrophic production was measured by incubating triplicate $10-40-\mathrm{mL}$ of samples and formaldehyde killed blanks $(2 \%$ final concentration) with $10 \mathrm{nmol} \mathrm{L}{ }^{-1}\left[{ }^{3} \mathrm{H}\right]$ leucine (final concentration, specific activity $157 \mathrm{Ci} \mathrm{mmol}^{-1}$; Amersham) in the dark at in situ temperature for $1-12 \mathrm{~h}$ depending on the water mass and the expected prokaryotic activity (Kirchman et al. 1985). Thereafter, the incubation was terminated by adding formaldehyde ( $2 \%$ final concentration) to the samples. The fixed samples were filtered through $0.2-\mu \mathrm{m}$ polycarbonate filters $(25-\mathrm{mm}$ filter diameter; Millipore) supported by Millipore HAWP filters. Subsequently, the filters were rinsed three times with $10 \mathrm{~mL}$ of $5 \%$ ice-cold trichloroacetic acid, dried and placed in scintillation vials. Scintillation cocktail $(8 \mathrm{~mL}$ CanberraPackard Filter Count) was added and after $18 \mathrm{~h}$, counted in a liquid scintillation counter (LKB Wallac Model 1212). The mean disintegrations per minute (DPM) of the formaldehyde-fixed blanks were subtracted from the mean DPM of the respective samples and the resulting DPM converted into leucine incorporation rates. Prokaryotic carbon biomass production was estimated using the conservative theoretical conversion factor of $1.55 \mathrm{~kg} \mathrm{C}$ $\mathrm{mol}^{-1}$ Leu incorporated assuming no internal isotope dilution (Kirchman and Ducklow 1993).

Respiratory activity of the electron transport system (ETS) - ETS activity was measured following the modifications of the tetrazolium reduction technique as described in Arístegui and Montero (1995). Some minor modifica- tions of the method were made to increase its sensitivity. Briefly, about 10 liters of sample was filtered through a Whatman GF/F filter (47-mm diameter). Filters were folded into cryovials and immediately stored in liquid nitrogen until analysis in the laboratory. Back in the laboratory, the filters with the collected material were homogenized in $2.5-\mathrm{mL}$ phosphate buffer with a Teflonglass tissue grinder at $0-4^{\circ} \mathrm{C}$ for $1.5 \mathrm{~min}$. A $0.9-\mathrm{mL}$ aliquot of the crude homogenate was incubated in duplicate with $0.5 \mathrm{~mL}$ of substrate solution and $0.35 \mathrm{~mL}$ of 2-(4-iodophenyl)-3-(4-nitrophenyl)-5-phenyltetrazolium chloride (INT) at $18^{\circ} \mathrm{C}$ for $20 \mathrm{~min}$. The reaction was quenched by adding $0.25 \mathrm{~mL}$ of a mixture of formalin and phosphoric acid. The quenched reaction mixture was centrifuged at $4000 \mathrm{~g}$ at $4{ }^{\circ} \mathrm{C}$ for $20 \mathrm{~min}$ and the absorbance of the particle-free solution measured in a Beckman DU-650 spectrophotometer at $490 \mathrm{~nm}$ and $750 \mathrm{~nm}$ wavelengths after adjusting the sample to room temperature. Readings at $750 \mathrm{~nm}$, to correct for turbidity, were always negligible. In addition to the samples, duplicate controls were run by replacing the crude extract with a clean Whatman GF/F filter homogenized in phosphate buffer. ETS activity was calculated using the equation given in Packard and Williams (1981):

$$
\begin{aligned}
& \operatorname{ETS}_{\text {ASSAY }}\left(\mathrm{mmol} \mathrm{O}_{2} \mathrm{~m}^{-3} \mathrm{~h}^{-1}\right)= \\
& \mathrm{H} \times \mathrm{S} \times\left(\mathrm{OD}_{\text {corr }}\right) /(1.42 \times \mathrm{V} \times \mathrm{f} \times \mathrm{t} / 60) \\
& \times 22.4
\end{aligned}
$$

where $\mathrm{H}$ is the volume of the homogenate (in $\mathrm{mL}$ ), $\mathrm{S}$ is the volume of the quenched reaction mixture (in $\mathrm{mL}$ ), $\mathrm{OD}_{\text {corr }}$ is the absorbance of the sample measured at 490-nm wavelength and corrected for blank absorbance, $\mathrm{V}$ is the volume (in liters) of the seawater filtered through the Whatman GF/F filter, $f$ is the volume of the homogenate used in the assay (in $\mathrm{mL}$ ), $\mathrm{t}$ is the incubation time (in minutes), 60 converts minutes to hours, the factor 1.42 converts the INT-formazan formed to oxygen units (in $\mu \mathrm{L}$ ), 
and 22.4 converts the $\mu \mathrm{L} \mathrm{O}$ to $\mu \mathrm{mol} \mathrm{O}_{2}$. ETS activity was corrected to in situ temperature using the following equation:

$$
\mathrm{ETS}_{\text {INSITU }}=\operatorname{ETS}_{\mathrm{ASSAY}} \times \mathrm{e}^{[\mathrm{Ea} / \mathrm{R} \times(1 / \text { Tass }-1 / \text { Tis })]}
$$

where Ea is the Arrhenius activation energy (in $\mathrm{kJ} \mathrm{mol}^{-1}$ ), $\mathrm{R}$ is the gas constant, and Tass and Tis are the temperatures (in degrees Kelvin) in the assay and in situ, respectively. Calculated activation energy of $67 \mathrm{~kJ} \mathrm{~mol}^{-1}$ was used (Arístegui and Montero 1995). Actual rates of oxygen consumption in carbon units $(\mathrm{R})$ were calculated assuming R:ETS $=0.09$ (see details in the Discussion section) and a respiratory quotient of 1 .

Particulate organic carbon (POC) and organic nitrogen (PON) - Samples (4-6 liters) for POC and PON were filtered through combusted $\left(450^{\circ} \mathrm{C}\right.$ for $\left.12 \mathrm{~h}\right) 25-\mathrm{mm}$ Whatman GF/F filters. The filters were wrapped in combusted aluminum foil and kept frozen at $-20^{\circ} \mathrm{C}$ until processed. In the laboratory, the filters were thawed and dried overnight at $65^{\circ} \mathrm{C}$ in a desiccator under $\mathrm{HCl}$ fumes to remove carbonates and finally, dried overnight in a desiccator with silica gel. Prior to analysis, samples were packed into ultra-clean tin caps. The carbon analyses were performed on a Perkin-Elmer $2400 \mathrm{CHN}$ (carbon, hydrogen, nitrogen) elemental analyzer according to the JGOFS (Joint Global Ocean Flux Study) protocol (UNESCO 1994). Measurements of organic material from low-volume filtrations may be questionable due to the possible sorption of DOM on the filter material (Turnewitsch et al. 2007). Hence, sorption blanks were determined for each station by placing two Whatman GF/F filters together on the filter holder while filtering the water sample. The adsorbed organic $\mathrm{C}$ and $\mathrm{N}$ collected by these filters was measured as described above and subtracted from the POC- and PONcontent of the corresponding particulate samples.

Total organic carbon (TOC)-For TOC determinations, $8 \mathrm{~mL}$ of the unfiltered sample was pipetted into combusted $\left(450^{\circ} \mathrm{C}\right.$ for $\left.4 \mathrm{~h}\right)$ glass ampoules, immediately acidified with 3-4 drops of $45 \% \mathrm{H}_{3} \mathrm{PO}_{4}$ and the ampoule sealed. Samples were stored at $-20^{\circ} \mathrm{C}$ until analysis. TOC analysis was performed using the high-temperature combustion method on a modified Shimadzu TOC-5000A. The absorbance of the $\mathrm{CO}_{2}$ evolving from the combusted TOC was detected with an external infrared cell (LiCor Model LI-6252) and quantified as peak area by the Shimadzu integrator. Per sample, $100 \mu \mathrm{L}$ was automatically injected in quadruplicate with a Shimadzu ASI-5000A autosampler on a platinized aluminum catalyst (Elemental Microanalysis) at a combustion temperature of $680^{\circ} \mathrm{C}$ (Benner and Strom 1993). Standards were prepared with potassium hydrogen phthalate (Baker) in Milli-Q water. The overall analytical precision was always $<3 \%$. The reported TOC concentrations resemble DOC (water filtered through rinsed $0.2-\mu \mathrm{m}$ polycarbonate filters) because there was no significant difference between corresponding TOC and DOC samples (data not shown). Occasionally, the DOC samples were even slightly higher than the corresponding TOC values.
Dissolved organic nitrogen (DON)-For DON determinations, $10-100 \mathrm{~mL}$ of filtered (through combusted Whatman GF/F glass-fiber filters) water was collected in acidrinsed polyethylene bottles. The DON and DOP (data not shown) analyses were performed simultaneously according to the method of Valderrama (1981). This procedure is based on an alkaline persulfate digestion (at $120^{\circ} \mathrm{C}$ in an autoclave for $90 \mathrm{~min}$ ) over a wide $\mathrm{pH}$ range starting at $\mathrm{pH} 9$ and ending at pH 4 using boric acid and sodium hydroxide. The resulting $\mathrm{NH}_{4}^{+}$was measured using an autoanalyzer (Technicon Random Access Automated Chemistry System, TRAACS). DON concentrations were obtained by subtracting the sum of the concentration of the inorganic nitrogen species $\left(\mathrm{NH}_{4}^{+}+\mathrm{NO}_{3}^{-}+\mathrm{NO}_{2}^{-}\right)$from the corresponding total dissolved $\mathrm{N}$ concentrations. To check the efficiency of DON determinations, 10 different compounds containing organic $\mathrm{N}$ were measured in parallel with the samples. For this reference material, the recovery efficiency of organic nitrogen was $92 \%$ of the calculated organic nitrogen concentration.

Statistical analysis-To check the normality of the individual data sets, the Kolmogorov-Smirnoff test was used. If normality was not attained, the nonparametric Mann-Whitney test (for comparison of two independent variables) was applied. Data were log-transformed to attain normality before Spearman's rank correlation coefficients were calculated.

\section{Results}

Prokaryotic abundance $(P A)$ and prokaryotic heterotrophic production $(P H P)$ - PA ranged between $2.2 \times 10^{5}$ cells $\mathrm{mL}^{-1}$ and $3.9 \times 10^{5}$ cells $\mathrm{mL}^{-1}$ at $100-\mathrm{m}$ depth and from $0.1 \times 10^{5}$ cells $\mathrm{mL}^{-1}$ to $0.8 \times 10^{5}$ cells $\mathrm{mL}^{-1}$ in the mesoand bathypelagic waters, decreasing exponentially with depth (Fig. 2A). No significant differences were found in the PA of the subsurface layer (100-m depth) between the SG and the NEqCC (Mann-Whitney, $p>0.05, n=42$; Fig. 2A). In the OML, intermediate, and deep-water masses, PA was, however, significantly higher in the $\mathrm{NEqCC}$ than in the corresponding water masses of the SG (Mann-Whitney tests; OML: $p<0.01, n=44$; AAIW: $p<0.001, n=22$; NEADW: $p<0.001, n=22$; LDW: $p<$ $0.001, n=43$; Fig. 2A).

PHP decreased with depth by three orders of magnitude (Fig. 2B) and followed the same vertical distribution as PA. The difference in PHP between both regions was not significant in the NEADW even though PHP was about twice as high in the NEqCC than in the SG. Cell-specific PHP decreased only by one order of magnitude (Fig. 2C) following the same pattern as bulk PHP. Cell-specific PHP was higher in the subsurface waters of the SG than in the NEqCC (Mann-Whitney, $p<0.01, n=22$ ), but not significantly different in the intermediate water masses and NEADW (Mann-Whitney, $p>0.05, n=22$ and $n=19$ for intermediate water masses and NEADW, respectively). Remarkably, cell-specific PHP was about three times higher in the LDW of the SG than of the NEqCC and higher than the cell-specific PHP of NEADW and intermediate waters (Fig. 2C). Prokaryotic turnover time 

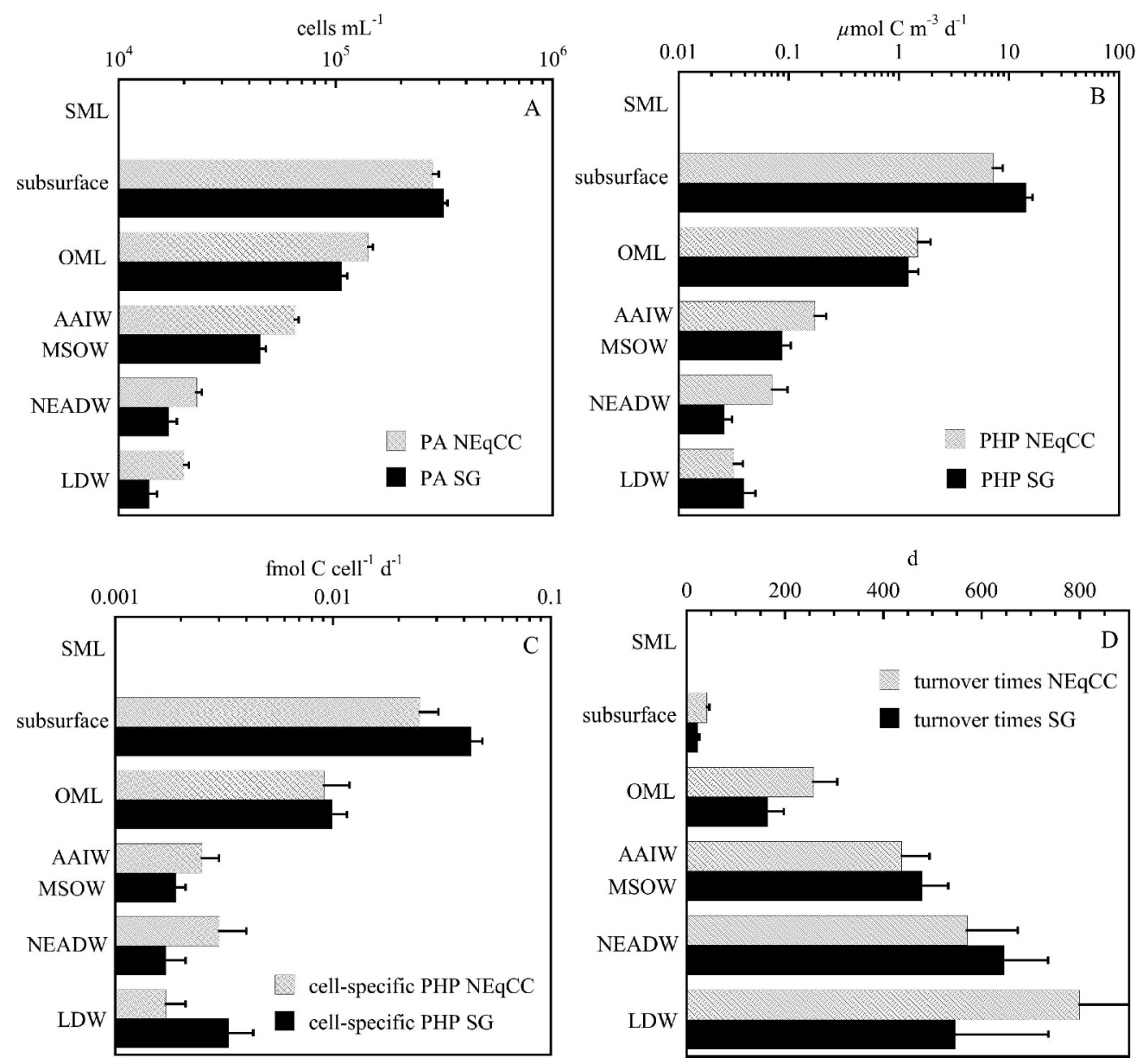

Fig. 2. Distribution of basic prokaryotic parameters in the different water masses in the subtropical gyre (SG) and North Equatorial Counter Current (NEqCC) zones (see Table 1 for depths of each water mass). (A) prokaryotic abundance (cell-1 $\mathrm{mL}^{-1}$ ), (B) prokaryotic heterotrophic production ( $\mu \mathrm{mol} \mathrm{C} \mathrm{m}^{-3} \mathrm{~d}^{-1}$ ), (C) cell-specific prokaryotic heterotrophic production (fmol C cell ${ }^{-1} \mathrm{~d}^{-1}$ ), (D) turnover time (d). Bars represent means \pm standard error.

(C-biomass/PHP) increased from $22 \pm 3 \mathrm{~d}$ in the subsurface layer to $798 \pm 193 \mathrm{~d}$ in the LDW with no significant differences between the water masses in the NEqCC and the SG (Fig. 2D).

Potential respiration estimated via ETS measurementsPotential respiration rates as determined by ETS measurements decreased over the sampled depth-range by two orders of magnitude (Fig. 3A). ETS values in the SML were significantly higher in the NEqCC than in the SG (Mann-Whitney, $p<0.02, n=21$ ). No significant differences were found, however, in the ETS of the subsurface and the OML between the SG and the NEqCC (Mann-Whitney, $p>0.05, n=24$ and $n=46$ respectively; Fig. 3A). Remarkably, ETS, like PA and PHP (except in the LDW), was higher in all the deep-water masses of the NEqCC than in the SG (Mann-Whitney tests; AAIW: $p<$ $0.02, n=21$; NADW: $p<0.001, n=23$; LDW: $p<0.02, n$ $=21$; Fig. 3A). Although both, prokaryotic abundance (Fig. 2A) and potential respiration (Fig. 3A) decreased with depth, cell-specific ETS showed a different trend: first decreasing with depth to reach the lowest values in the intermediate water masses (AAIW and MSOW) and then increasing again, reaching the highest cell-specific ETS of all the water masses in the LDW (Fig. 3B). Cell-specific ETS was significantly higher in the deep-water masses (NEADW: Mann-Whitney, $p<0.02, n=23$; LDW: Mann-Whitney, $p<0.05, n=21$ ) of the NEqCC than in the SG, with a cell-specific ETS in the LDW of the NEqCC being two times higher than in the subsurface waters (Fig. 3B). A pronounced latitudinal gradient in ETS was detectable below 1000-m depth with increasing values towards the south, particularly in the NEADW (core around 2750-m depth; Fig. 4A).

Particulate (POM) and dissolved organic matter (DOM) distribution in the water column - Like ETS, also POC but not DOC (compare Figs. 4B and C) increased towards the south along the Mid-Atlantic Ridge in the deep waters, except in the LDW, where the influence of POC resuspended from the ocean bottom (as inferred from the high $\mathrm{C}: \mathrm{N}$ ratios) was apparent. Overall, POC concentrations were significantly higher in the water masses of the NEqCC than of the SG (Mann-Whitney, $p<0.0001, n=$ 

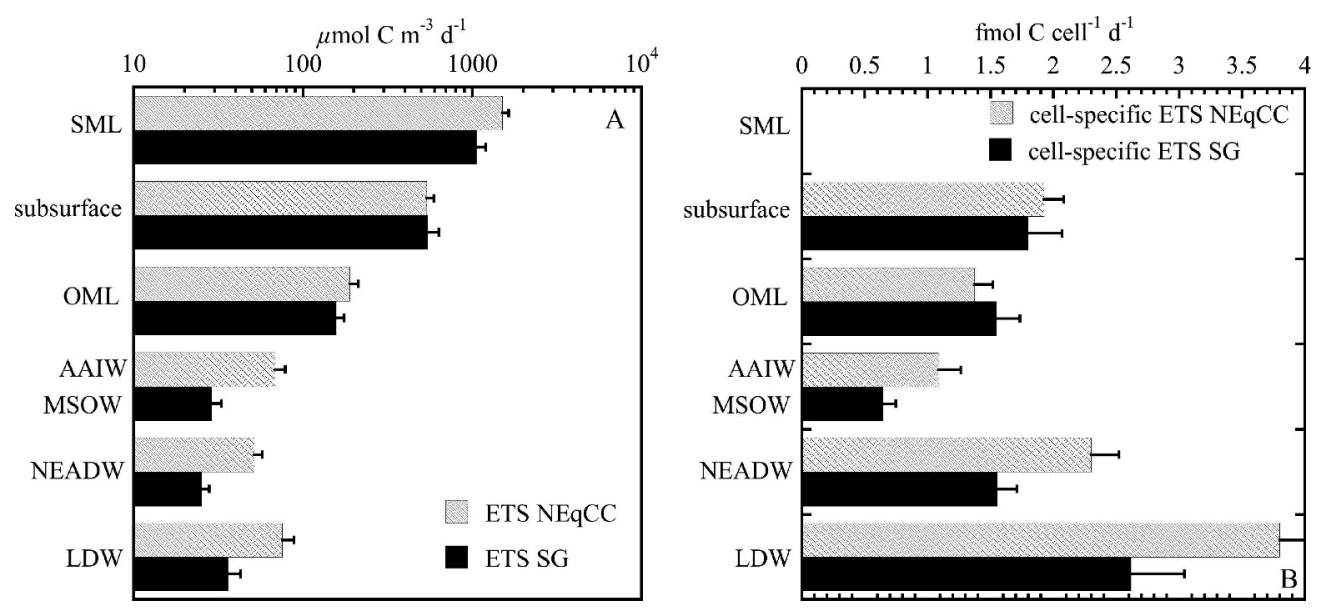

Fig. 3. Distribution of (A) ETS ( $\mu \mathrm{mol} \mathrm{C} \mathrm{m}^{-3} \mathrm{~d}^{-1}$ ) and (B) cell-specific ETS (fmol C cell-1 $\mathrm{d}^{-1}$ ) throughout the water column along the subtropical gyre (SG) and North Equatorial Counter Current (NEqCC) zones (see Table 1 for depths of each water mass). Bars represent mean \pm standard error.

163; Fig. 5A) except in the LDW (Mann-Whitney, $p>$ $0.05, n=22$ ). Strikingly, POC concentrations were higher in the OML than in the water masses above and below (Fig. 5A), a fact that could be due to increasing density and reduced sinking rates in microdensity gradients between water masses.

PON concentrations were generally an order of magnitude lower than POC (Fig. 5B). In contrast to POC concentrations, PON was higher in almost all the water masses of the SG region (compare Fig. 5A and B). The molar $\mathrm{C}: \mathrm{N}$ ratio of the POM clearly increased with depth (Fig. 5C). Throughout the entire water column, the mean $\mathrm{C}: \mathrm{N}$ ratio of POM was significantly higher in the NEqCC than in the SG (Mann-Whitney, $p<0.01, n=157$ ), due to the higher POC and lower PON concentrations in the $\mathrm{NEqCC}$ as compared to the SG.

In contrast to POC, DOC concentrations remained rather stable throughout the water column (Fig. 5D). There was no significant difference in DOC concentrations between the NEqCC and SG water masses (MannWhitney, $p>0.05$ for all water masses; Figs. 4C, 5D). DON concentrations were generally one order of magnitude lower than DOC values, slightly decreasing with depth (Fig. 5E). Higher DON concentrations were obtained for the deep-water masses of the $\mathrm{NEqCC}$ than of the $\mathrm{SG}$, except in the LDW (Mann-Whitney tests; OML: $p<0.02$, $n=48$; AAIW: $p<0.03, n=24$; NADW: $p<0.05, n=26$; LDW: $p>0.20, n=22$ ). In contrast to the POM pool (Fig. 5C), the C: N molar ratio of the DOM pool (Fig. 5F) showed essentially no variation with depth. The $\mathrm{C}: \mathrm{N}$ of the DOM was significantly lower in the NEqCC than in the SG (Mann-Whitney, $p<0.0002, n=141$ ).

\section{Discussion}

The average depth distribution of the $\mathrm{C}: \mathrm{N}$ molar ratio of the POM pool (Fig. 5C) shows that the ratio is substantially higher in the meso- and bathypelagic waters than in the upper 200-m layer, but without a clear depth gradient across these layers. Only the LDW of the Subtropical Gyre shows a significant increase in the C:N ratio due to a marked enhancement in the POC concentrations (but not in $\mathrm{PON}$ ), possibly caused by lateral advection of $\mathrm{N}$-depleted POM. The high $\mathrm{C}: \mathrm{N}$ ratios of the POM pool in the dark ocean (about two times higher than the average $\mathrm{C}: \mathrm{N}$ ratio of $\mathrm{DOM}$; Fig. $5 \mathrm{~F}$ ) indicate a preferential utilization of PON by the microbial assemblages. However, the lack of a clear depth gradient in the $\mathrm{C}: \mathrm{N}$ ratios suggests that the source of this POM may not be related to the sinking flux from the overlying surface ocean. Figure 4B illustrates a latitudinal POC gradient, increasing from $35^{\circ} \mathrm{N}$ to $5^{\circ} \mathrm{N}$, with higher POC concentrations in the deep ocean near the equator. The gradient is more apparent below 1000-m depth, coinciding with a similar latitudinal trend in ETS (Fig. 4A). Taken together, this suggests a predominant lateral transport of suspended particles. Although the ranges of variability in POC and ETS are low, POC is strongly positively correlated with ETS (Spearman's $\rho=0.70, p<0.02$; Fig. 6A) in the NEADW of the SG but not in the NEqCC. The lack of a correlation between POC and ETS in the NEqCC is probably a consequence of the more refractory POM compared to the SG (Fig. 5A-C). The AAIW also shows a strong correlation between POM and microbial activity. POC (Fig. 6B) and PON are both correlated with ETS (Spearman's $\rho=0.82, p<0.0001$ for POC and 0.93, $p<$ 0.0001 for PON) and cell-specific ETS (Spearman's $\rho=$ $0.83, p<0.002$ for POC and $0.66, p<0.02$ for PON). The fact that POM and ETS activity are strongly correlated along these water masses supports the hypothesis that deepwater prokaryotic activity depends to a large extent on suspended particles.

There are very few published studies relating particle flux and deep-water microbial metabolism, and these report contradictory results. Nagata et al. (2000) concluded from a study in the subarctic Pacific that the deep-water microbial activities are related to the sinking POC fluxes. Also, Simon et al. (2004) found that prokaryotic production in the 

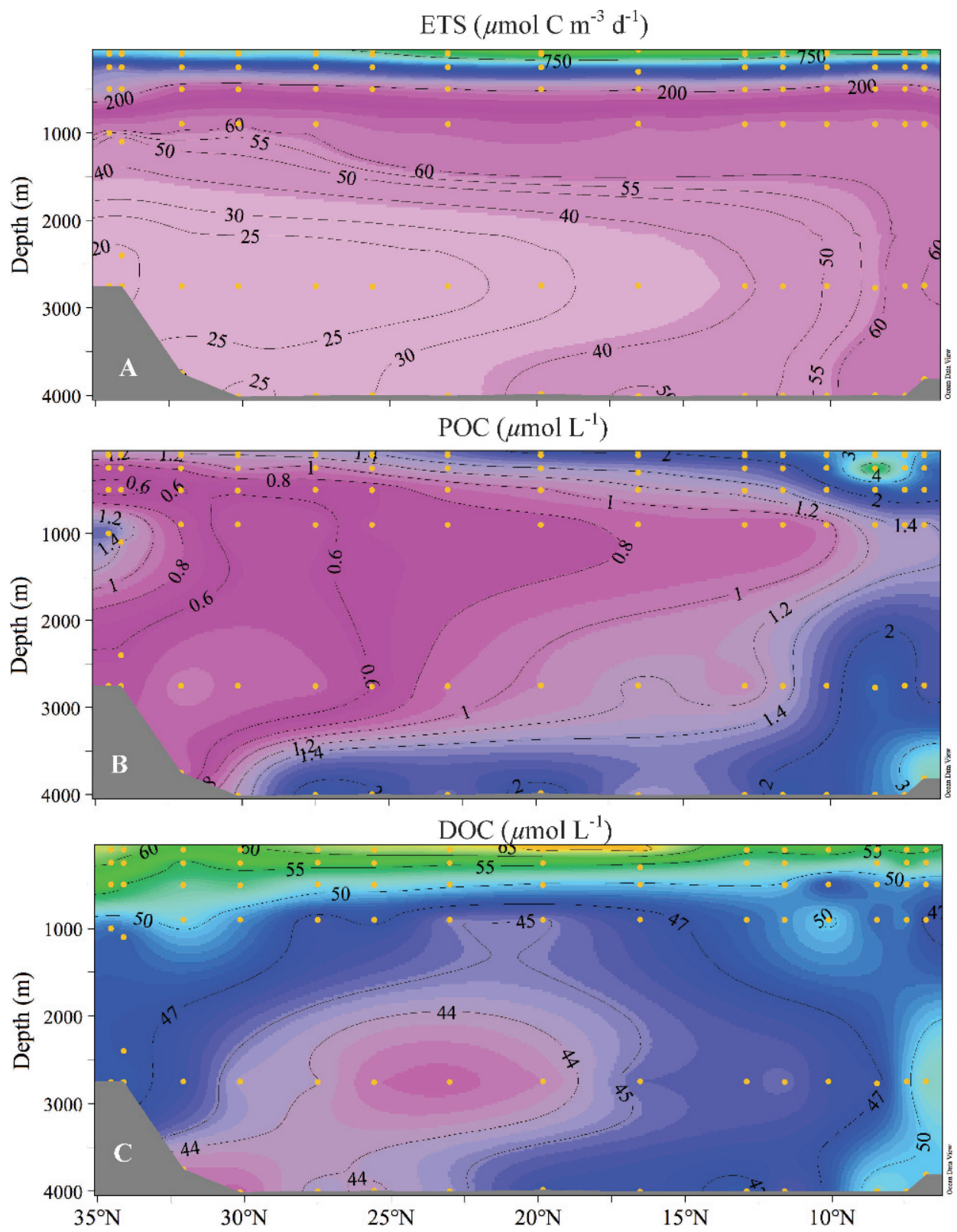

Fig. 4. Distribution of (A) ETS ( $\mu$ mol C m$\left.{ }^{-3} \mathrm{~d}^{-1}\right)$, (B) POC $\left(\mu \mathrm{mol} \mathrm{L}^{-1}\right),(\mathrm{C})$ and DOC $\left(\mu \mathrm{mol} \mathrm{L}{ }^{-1}\right)$ throughout the water column along a transect east of the Mid-Atlantic Ridge in the North Atlantic extending from Sta. 40 to 16 as shown in Fig. 1.

mesopelagic waters was significantly correlated to primary production and surface chlorophyll in the Southern Ocean. Moreover, Anderson et al. (2007) concluded for the oxygen minimum zone of the Arabian Sea, that the modeled vertical export flux of detritus was sufficient to account for the measured bacterial production below the euphotic zone in the Arabian Sea. Ducklow (1993) found that the rates of DOC release from the sinking particle flux are sufficient to support bacterial production in the Gulf of Oman; however, they are insufficient to meet the bacterial carbon demand in the open Arabian Sea. Additionally, Hansell and Ducklow (2003) found that only prokaryotic abundance and not activity was related to the POC flux in the
Arabian Sea, suggesting that deep-ocean prokaryotic abundance and activity might depend on the long-term averages of POC flux and not on the more immediate flux. Recently, Steinberg et al. (2008), found that the POC flux is too low to meet the bacterial and mesozooplankton carbon demand at two sites in the Pacific. These authors proposed diel vertical migration of zooplankton and the associated POC transfer as a mechanism to provide additional organic carbon for mesopelagic metabolism to resolve the discrepancy between the POC flux and the mesopelagic carbon demand. Taken together, these contradictory findings may reflect variability in the transfer efficiency of organic material from the euphotic layer to the deep sea (Francois 

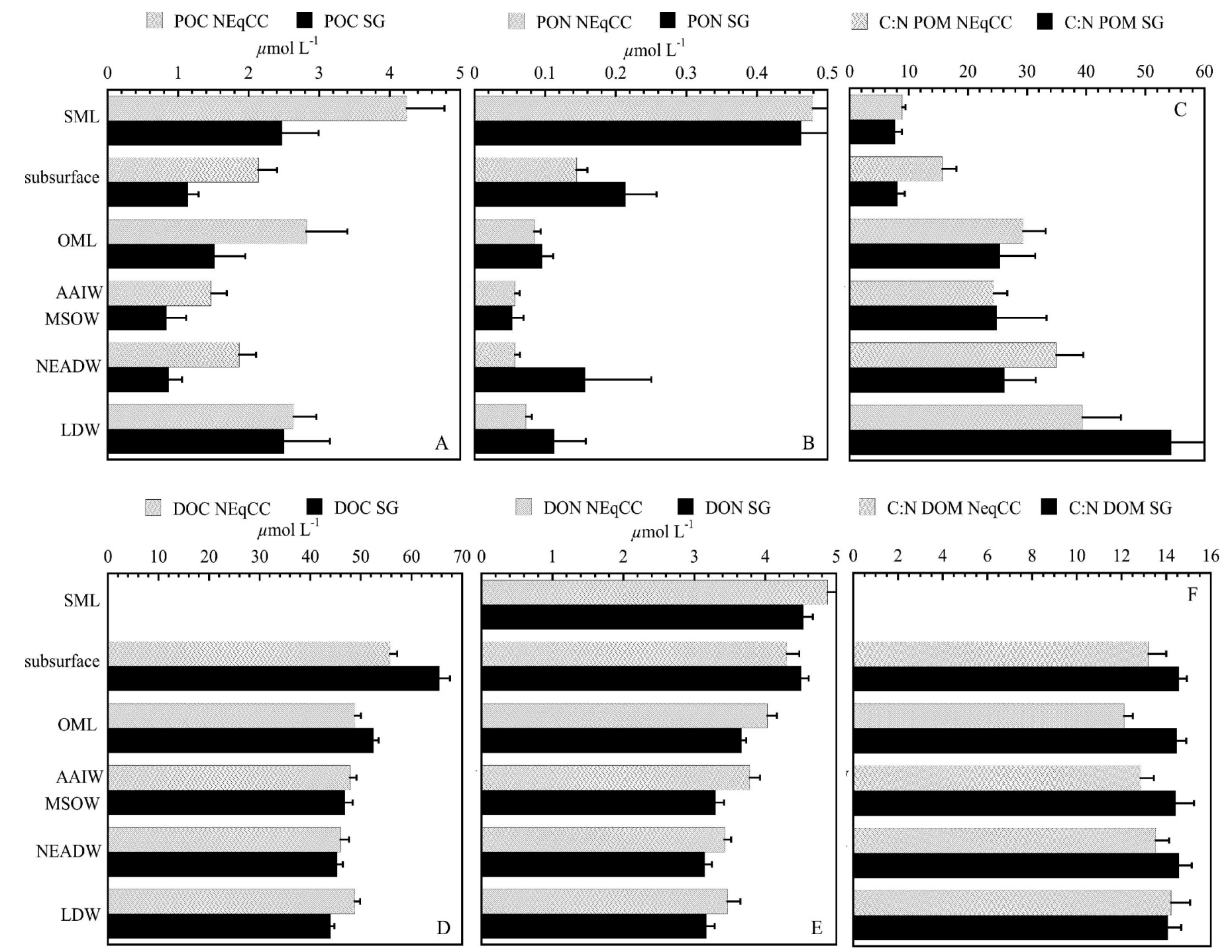

PON NEqCC $\square$ PON SG

C:N POM NEqCC $\quad$ C:N POM SG

Fig. 5. Distribution of basic prokaryotic parameters in the different water masses of the subtropical gyre (SG) and North Equatorial Counter Current (NEqCC) zones. (A) POC $\left(\mu \mathrm{mol} \mathrm{L}^{-1}\right)$, (B) PON $\left(\mu \mathrm{mol} \mathrm{L}^{-1}\right),(\mathrm{C}) \mathrm{POC}$ : PON molar ratio, (D) DOC $(\mu \mathrm{mol} \mathrm{L}-1),(\mathrm{E})$ DON $\left(\mu \mathrm{mol} \mathrm{L}{ }^{-1}\right),(F)$ DOC: DON molar ratio. See Table 1 for depths of each water mass. Bars represent means \pm standard error.

et al. 2002) or differences in the magnitude of other carbon sources, like lateral transport of suspended POM and DOM. Arístegui et al. (2005b) invoked a coastal-ocean lateral transport of POM to explain the high prokaryotic metabolic rates measured in the mesopelagic zone of the Canary Current, where POM concentrations are several times higher than in the open-ocean waters of the Subtropical Gyre (Neuer et al. 2007). A recent box-model study of the Canary Current region (Alonso-González unpubl.) supports this view, providing evidence that suspended POM may account for up to $60 \%$ of the remineralization rates in the mesopelagic zone.

In order to examine the balance between vertical carbon flux and the prokaryotic carbon demand $(\mathrm{PCD}=\mathrm{PHP}+$ $\mathrm{R})$, we estimated the sinking POC flux using the model of Antia et al. (2001), based on sediment-trap data collected from the subpolar region to the oligotrophic subtropical North Atlantic. The POC available at a depth " $z$ " (in $\mathrm{m}$ ) is derived from the following equation:

$\operatorname{POC}\left(\operatorname{mmol~C~m}{ }^{-3} \mathrm{~d}^{-1}\right)=0.068 \times \mathrm{PP}^{1.77} \times \mathrm{z}^{-1.68}$

where PP is the primary production of the mixed-layer (in mmol $\mathrm{C} \mathrm{m}^{-2} \mathrm{~d}^{-1}$ ).

The potentially available POC is calculated using the lower and upper value of the range of primary production (12-90 mmol C m $\mathrm{m}^{-2} \mathrm{~d}^{-1}$ ) provided by Antia et al. (2001) for the NE Atlantic. We assume that a primary production of $12 \mathrm{mmol} \mathrm{C} \mathrm{m} \mathrm{C}^{-1}$ is representative for the $\mathrm{SG}$ and $90 \mathrm{mmol} \mathrm{C} \mathrm{m} \mathrm{C}^{-2} \mathrm{~d}^{-1}$ for the $\mathrm{NEqCC}$ region. Using these primary production rates, the available $\mathrm{POC}$ is only sufficient to support the prokaryotic carbon demand (PCD) in the euphotic zone (Table 2), whereas below the subsurface waters, the PCD exceeds POC availability. The gap between PCD and POC increases with depth. The main process responsible for the increasing difference between 

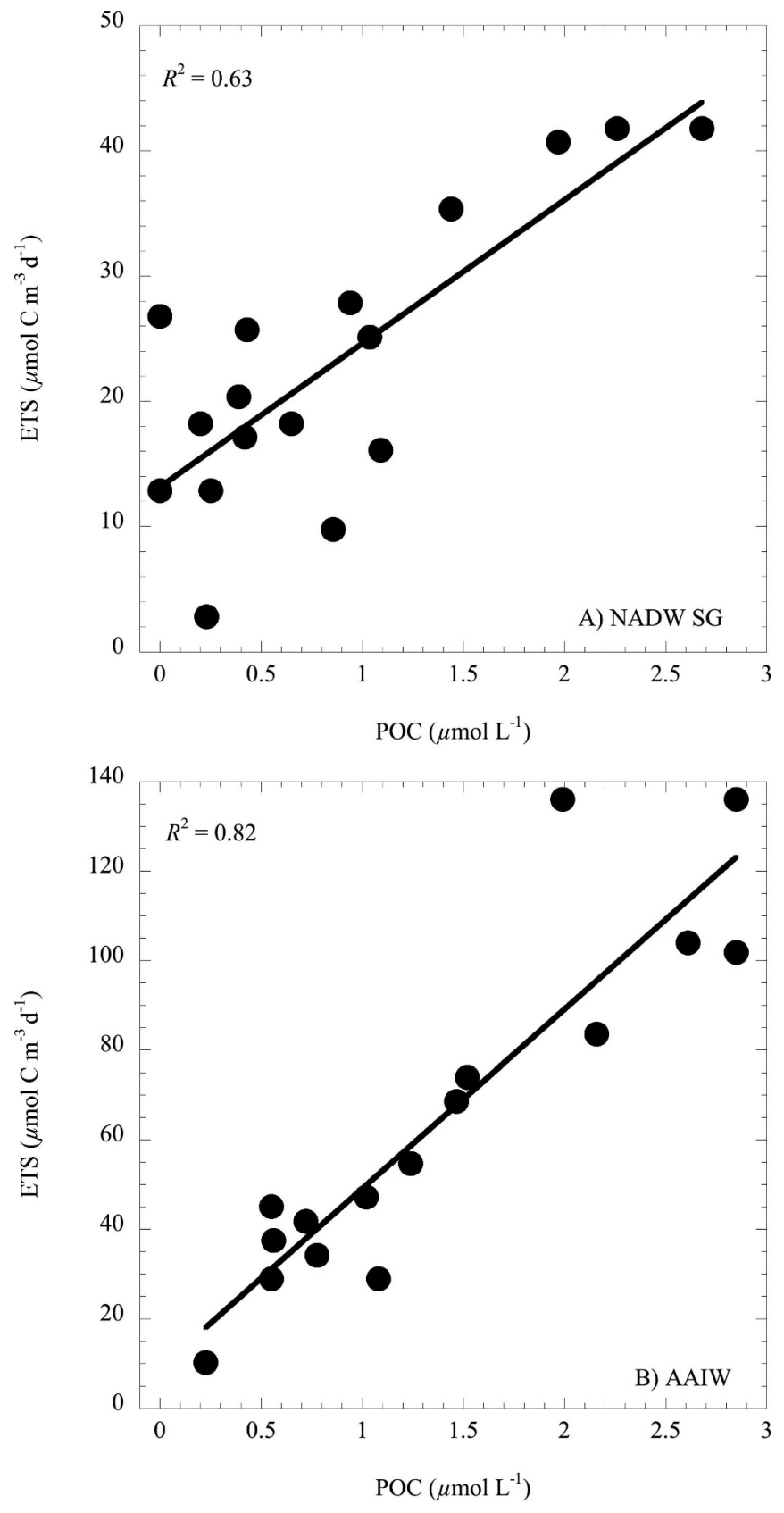

Fig. 6. Relation between ETS $\left(\mu \mathrm{mol} \mathrm{C} \mathrm{m} \mathrm{m}^{-3} \mathrm{~d}^{-1}\right)$ and POC $\left(\mu \mathrm{mol} \mathrm{L}{ }^{-1}\right)$ in the NEADW of the (A) SG, and in the (B) AAIW. Data are derived from Fig. 5A (for POC) and Fig. 3A (for ETS).

PCD and POC availability is microbial respiration, because PHP decreases 10 times more with depth than respiration (R). To further constrain prokaryotic carbon demand, a PGE of 0.04 was used as well (Table 2), based on a compilation of data of PHP and R from the global dark ocean (J. Arístegui unpubl.). Also the OUR (oxygen utilization rates) for the mesopelagic zone in the North and South Atlantic are given in Table 2 (Jenkins 1982; Jenkins and Wallace 1992; Brea 2008). Generally, PCD estimated via ETS is similar to that obtained by using the prokaryotic growth efficiency in the mesopelagic zone, but higher in the bathypelagic. This may be caused by either overestimating the ETS in the bathypelagic (by using an inappropriate R:ETS ratio), or by underestimating the PCD by using a too high PGE or by underestimating PHP.

It is unlikely that the disparity between POC fluxes and PCD is caused by an overestimation of R. There is some uncertainty related to ETS measurements because ETS provides, as other enzymatic measurements, only potential rates, which need to be converted to actual rates by conversion factors. ETS has been shown, however, to be closely correlated to actual oxygen consumption measurements in lakes (Del Giorgio 1992), the deep North Atlantic (Reinthaler et al. 2006) and the epipelagic ocean using a large global data set (Arístegui and Montero 1995). Christensen et al. (1980), working with marine bacteria cultures, found that the R:ETS of bacteria during the exponential growth phase ranges between 0.6 and 1.7, whereas in the senescent phase this ratio drops to 0.09 . In the present study we have applied an R: ETS ratio of 0.09 to convert ETS measurements to respiration rates assuming that only a fraction of the bacterial community is metabolically active. However, this ratio (and hence R) might be somewhat higher at least in the mesopelagic zone. Recently, Arístegui et al. (2005b) measured R and ETS in the mesopelagic waters of the Canary Region, obtaining a $\mathrm{R}$ : ETS of $0.68 \pm 0.11$, in agreement with a highly active prokaryotic assemblage, as confirmed by several other concomitantly measured proxies for bacterial activity. This latter ratio, however, may be not applicable to the bacterial assemblages in the present study, because the mesopelagic waters of the Canary region are characterized by much higher suspended POM concentrations than the water masses investigated in this study. Anyway, for the purpose of our study, the R derived from ETS (using an R: ETS ratio of 0.09) may represent an underestimation (but unlikely an overestimation) of the actual $\mathrm{R}$ in the dark ocean. Thus, we conclude that there is an imbalance between the POC available from the sinking flux and oxygen consumption in the dark ocean, particularly in the bathypelagic zone where ETS and POC are significantly correlated. Jenkins and coworkers (Jenkins 1982; Jenkins and Wallace 1992) and Brea (2008) estimated OUR for the mesopelagic waters (200-1000 m) of the North Atlantic and South Atlantic Subtropical Gyres, respectively. This approach has its own inherent uncertainty, due to the fact that water masses might mix while aging. Our ETS-derived $\mathrm{R}$ rates are in good agreement with the biogeochemical OUR estimates (Table 2), although OUR is somewhat higher than the ETS-derived R, as expected if the latter represents most likely an underestimation. In any case, both the OUR and ETS-derived $\mathrm{R}$ rates are higher than the estimated sinking POC reaching the lower mesopelagic zone. The gap between POC supply and respiration increases towards the bathypelagic ocean. In summary, although we are aware of the degree of uncertainty in $\mathrm{R}$ derived from ETS and also in the OUR (obtained from changes in the biogeochemical fields), the two independent approaches yield comparable estimates, which do not match with the calculated sinking fluxes of POC.

Besides the uncertainties in ETS measurements, decompression of samples prior to measuring prokaryotic 


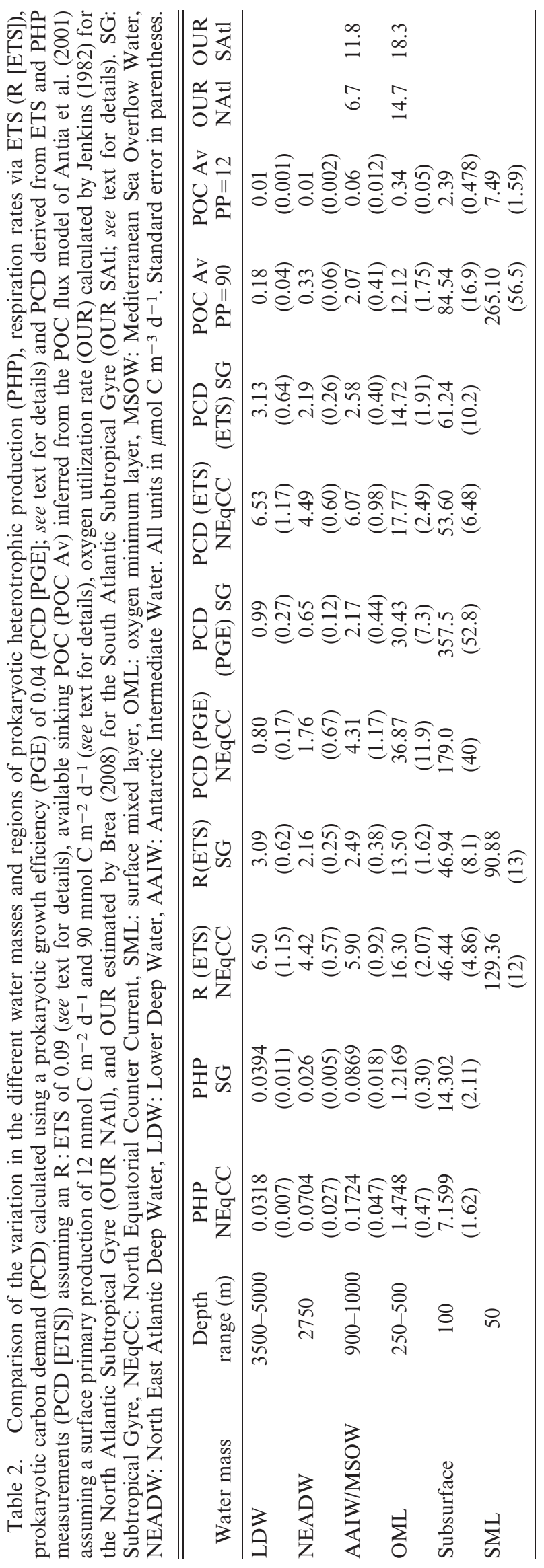

production by leucine incorporation might introduce biases. It has been shown that metabolic rates of deep-sea bacterioplankton incubated under in situ pressure conditions were $4.5 \pm 4.5$ (mean $\pm \mathrm{SD} ; n=19$ ) times higher than under decompressed conditions (Tamburini et al. 2003). If this applies also to our deep-water samples, the actual prokaryotic carbon demand would be even higher and hence, the gap between POC supply and carbon demand wider.

Apart from these uncertainties in the carbon demand estimates in the meso- and bathypelagic realm, POC supply estimates might be biased as well. Sediment traps are known to preferentially collect fast-sinking particles leaving buoyant or slow-sinking particles underrepresented (Honjo et al. 1984). Nevertheless, the POC flux derived from the model of Antia et al. (2001) is corrected for ${ }^{230} \mathrm{Th}$; hence, it should not underestimate the actual flux. The thorium approach has been used to calibrate sediment traps (Scholten et al. 2001) and suggests that for any given site, the efficiency of the shallower $(<1500-\mathrm{m}$ depth) traps is consistently lower than that of the deep traps at the same site. This lower collection efficiency at shallower depths in moored deep-ocean conical traps is likely caused by a combination of effects. Higher turbulence at shallower depths than in deep waters might disrupt fragile, marine snow-type particles around moored sediment traps. Also swimmers are commonly more abundant at shallower waters than in the bathypelagic region which might feed on accumulating POM in the traps. The nature and hydrodynamic properties of the settling particles might also change with depth as particles are becoming more consolidated and denser through cycles of aggregation and disaggregation (Buesseler et al. 2007).

The slow-sinking or buoyant suspended POM might arise from partial remineralization of sinking particles or from lateral input of neutrally buoyant particles from distant sources, like ocean margins. A recent study in the Canary Current region indicates that POM collected with bottles largely contributes to the carbon flux in the dark ocean (Alonso-González unpubl.). Thus, lateral transport of suspended particles might at least partly compensate for the observed imbalance between estimated prokaryotic carbon demands in the deep-ocean and export fluxes derived from sinking particles collected with sediment traps. However, because suspended POM concentrations are much smaller in the open ocean than in boundary currents or continental margins, other reasons must be invoked to account for the great deficit observed between the vertical carbon fluxes and oxygen consumption rates in open-ocean regions (Reinthaler et al. 2006). Steinberg et al. (2008) suggested that particle transfer by migrating mesozooplankton feeding in the euphotic layer and residing in the mesopelagic waters during the day might provide additional POC not captured by sediment traps and fuel mesopelagic carbon demand.

Evidence has been accumulating recently, suggesting a preferential particle-associated life mode of prokaryotes in the deep ocean. DeLong et al. (2006) found that deep-water prokaryotes are enriched in transposases, polysaccharide, and antibiotic synthesis genes and have high levels of 
chaperone-encoding genes, all suggesting a predominately particle-attached life mode. Arístegui et al. (2005b) and Reinthaler et al. (2006) reported an increasing nucleic acid content per cell with depth, indicative for a larger genome size which, in turn, might point to an opportunistic life style (Lauro and Bartlett 2007).

In summary, our data, together with other published evidence, clearly suggest that microbial life in the dark ocean is more closely related to suspended particles than hitherto assumed. Most of these particles are not collected with sediment traps. Thus, estimates of carbon availability derived exclusively from sinking fluxes lead to underestimations of the total carbon supply to prokaryotes, and hence to imbalances with the prokaryotic carbon demand. The correlation between the particulate fraction of the organic matter pool and the activity of prokaryotes could be expected a priori taking into account that cell-specific activities are higher in particle-associated than in free-living microbes, the latter thriving in a highly refractory organic matter environment. The notion that microbes grow associated with (colloidal) particles in the deep ocean, where they may maintain high metabolic activities, explains also the discrepancy found between the PCD and the sinking POC flux. However, the collection of samples in the water column with standard methods frequently leads to the disruption of the size-continuum of organic matter, possibly altering the colloidal microenvironment where microbial assemblages develop. Thus, new sampling strategies are needed to selectively collect deep-ocean particles to decipher the actual role of particle-attached vs. free-living microbes in the deep ocean's biogeochemical cycles.

\section{References}

Anderson, T. R., A. V. Ryabchenko, M. J. R. Fasham, and V. A. Gorchakov. 2007. Denitrification in the Arabian Sea: A 3D ecosystem modelling study. Deep-Sea Res. I 54: 2082-2119.

Antia, A., AND others. 2001. Basin-wide particulate carbon flux in the Atlantic Ocean: Regional export patterns and potential for atmospheric $\mathrm{CO}_{2}$ sequestration. Glob. Biogeochem. Cycles 15: 845-862.

Arístegui, J., S. Agustí, And C. Duarte. 2003. Respiration in the dark ocean. Geophys. Res. Lett. 30: 1041, doi:10.1029/ 2002GL016227.

- J. J. Middelburg, and C. M. Duarte. $2005 a$ Respiration in the mesopelagic and bathypelagic zones of the ocean. Oxford Univ. Press.

- C. M. Duarte, S. Agustí, M. Doval, X. A. ÁlvarezSalgado, and D. A. Hansell. 2002. Dissolved organic carbon support of respiration in the dark ocean. Science 298: 1967.

, - J. M. Gasol, and L. Alonso-Sáez. 2005b. Active mesopelagic prokaryotes support high respiration in the subtropical northeast Atlantic Ocean. Geophys. Res. Lett. 32: L03608, doi:10.1029/2004GL021863.

—, AND M. F. Montero. 1995. The relationship between community respiration and ETS activity in the ocean. J. Plankton Res. 17: 1563-1571.

Bauer, J. E., And E. R. M. Druffel. 1998. Ocean margins as a significant source of organic matter to the deep open ocean. Nature 392: 482-485.
Benner, R., And M. Strom. 1993. A critical evaluation of the analytical blank associated with DOC measurements by hightemperature catalytic oxidation. Mar. Chem. 41: 153-160.

BREA, S. 2008. Ciculación, mezcla, ventilación y mineralización de las aguas del Atlántico Sur.Ph.D. thesis. Univ. of Vigo.

Buesseler, K. O., AND OTHERS. 2007. An assessment of the use of sediment traps for estimating upper ocean particle fluxes. J. Mar. Res. 65: 345-416.

Сho, B. C., AND F. AzAm. 1988. Major role of bacteria in biogeochemical fluxes in the ocean's interior. Nature 332: 441-443.

Christensen, J. P., T. G. Owens, A. H. Devol, and T. T. PACKARD. 1980. Respiration and physiological state in marine bacteria. Mar. Biol. 55: 267-276.

Del Giorgio, P. A. 1992. The relationship between ETS (electron transport system) activity and oxygen consumption in lake plankton: A cross-system calibration. J. Plankton Res. 14: 1723-1741.

—, AND C. M. DuARTE. 2002. Respiration in the open ocean. Nature 420: 379-384.

Delong, E. F., And others. 2006. Community genomics among stratified microbial assemblages in the ocean's interior. Science 311: 496-503.

Ducklow, H. W. 1993. Bacterioplankton distribution and production in the northwestern Indian Ocean and Gulf of Oman, September 1986. Deep-Sea Res. 11: 753-771.

. 2000. Bacterial production and biomass in the oceans, p. 85-120. In D. L. Kirchman [ed.], Microbial ecology of the oceans. Wiley-Liss.

Francois, R., S. Honjo, R. Krishfield, and S. Manganini. 2002. Factors controlling the flux of organic carbon to the bathypelagic zone of the ocean. Glob. Biogeochem. Cycles 16: 1087, doi:10.1029/2001GB001722.

Hansell, D. A., And C. A. Carlson. 1998. Deep-ocean gradients of dissolved organic carbon. Nature 395: 263-266.

- AND $\longrightarrow$ 2002. Biogeochemistry of marine dissolved organic matter. Academic Press.

$\longrightarrow$, AND H. W. Ducklow. 2003. Bacterioplankton distribution and production in the bathypelagic ocean: Directly coupled to particulate organic carbon export? Limnol. Oceanogr. 48: 150-156.

Honjo, S. 1980. Material fluxes and modes of sedimentation in the mesopelagic and bathypelagic zones. J. Mar. Res. 38: 53-97.

- K. W. Doherty, Y. C. Agrawal, and V. L. Asper. 1984. Direct optical assessment of large amorphous aggregates (marine snow) in the deep ocean. Deep-Sea Res. 31: 67-76.

JenKins, W. J. 1982. Oxygen utilization rates in the North Atlantic Subtropical Gyre and primary production in oligotrophic systems. Nature 300: 246-248.

, AND D. W. R. Wallace. 1992. Tracer based inferences of new primary production in the Sea. Plenum Press.

Karl, D. M., G. A. Knauer, and J. H. Martin. 1988. Downward flux of particulate organic matter in the ocean: A particle decomposition paradox. Nature 332: 438-441.

Kirchman, D., E. K'Ness, and R. Hodson. 1985. Leucine incorporation and its potential as a measure of protein synthesis by bacteria in natural aquatic systems. Appl. Environ. Microbiol. 49: 599-607.

Kirchman, D. L., AND H. W. Ducklow. 1993. Estimating conversion factors for thymidine and leucine methods for measuring bacterial production, p. 513-517. In P. F. Kemp, B. F. Sherr, E. B. Sherr and J. J. Cole [eds.], Handbook of methods in aquatic microbial ecology. Lewis.

Lauro, F., And D. H. Bartlett. 2007. Prokaryotic lifestyles in deep sea habitats. Extremophiles 12: 15-25. 
McCave, I. N. 1975. Vertical fluxes of particles in the ocean. Deep-Sea Res. 22: 491-502.

. 1984. Size spectra and aggregation of suspended particles in the deep ocean. Deep-Sea Res. 31: 329-352.

MoritA, R. Y. 1984. Feast or famine in the deep sea. Dev. Ind. Microbiol. 25: 5-16.

Nagata, T., H. Fukuda, R. Fukuda, and I. Koike. 2000. Bacterioplankton distribution and production in the deep Pacific waters: Large-scale geographic variations and possible coupling with sinking particle fluxes. Limnol. Oceanogr. 45: 426-435.

Neuer, S., AND others. 2007. Biogeochemistry and hydrography in the eastern subtropical North Atlantic gyre. Results from the European time-series station ESTOC. Prog. Oceanogr. 72: $1-29$.

Packard, T. T., and P. J. L. B. Williams. 1981. Rates of respiratory oxygen consumption and electron transport in surface seawater from the Northwest Atlantic. Oceanol. Acta 4: $351-358$

Reinthaler, T., AND others. 2006. Prokaryotic respiration and production in the meso- and bathypelagic realm of the eastern and western North Atlantic basin. Limnol. Oceanogr. 51: $1262-1273$.

Scholten, J. C., And others. 2001. Trapping efficiencies of sediment traps from the deep Eastern North Atlantic: The 230Th calibration. Deep-Sea Res. II 48: 2383-2408.

Simon, M., B. Rosenstock, And W. Zwisler. 2004. Coupling of epipelagic and mesopelagic heterotrophic picoplankton production to phytoplankton biomass in the Antarctic polar frontal region. Limnol. Oceanogr. 49: 1035-1043.

-, N. A. Welschmeyer, And D. L. Kirchman. 1992. Bacterial production and the sinking flux of particulate organic matter in the subarctic Pacific. Deep-Sea Res. 39: 1997-2008.
Steinberg, D. K., B. A. Van Mooy, K. Buesseler, P. W. Boyd, T. Kobari, and D. M. Karl. 2008. Bacterial vs. zooplankton control of sinking particle flux in the ocean's twilight zone. Limnol. Oceanogr. 53: 1327-1338.

TAmburini, C., J. Garcin, And A. Bianchi. 2003. Role of deep-sea bacteria in organic matter mineralization and adaptation to hydrostatic pressure conditions in the NW Mediterranean Sea. Aquat. Microb. Ecol. 32: 209-218.

TURNEWITSCH, R., AND OTHERs. 2007. Determination of particulate organic carbon (POC) in seawater: The relative methodological importance of artificial gains and losses in two glass-fiberfilter-based techniques. Mar. Chem. 105: 208-228.

UNESCO. 1994. Protocols for the joint global ocean flux study (JGOFS) core measurement. Intergovernmental Oceanographic Commission, Manual and Guides 29.

VALDERRAMA, J. 1981. The simultaneous analysis of total nitrogen and total phosphorus in natural waters. Mar. Chem. 10: 109-122.

Varela, M., H. M. van Aken, E. Sintes, and G. J. Herndl. 2008. Latitudinal trends of Crenarchaeota and bacteria in the mesoand bathypelagic water masses of the Eastern North Atlantic. Environ. Microbiol. 10: 110-124.

Verdugo, P., A. A. Alldredge, F. Azam, D. L. Kirchman, U. Passow, AND P. SANTSChI. 2004. The oceanic gel phase: A bridge in the DOM-POM continuum. Mar. Chem. 92: $67-85$
Edited by: Wade H. Jeffrey

Received: 16 April 2008

Accepted: 29 August 2008

Amended: 08 September 2008 